\title{
Simulation modeling of cAMP induced Dictyostelium aggregation using object-oriented Pharo programming language
}

\author{
K. A. Nizheradze \\ Bogomolets National Medical University \\ 13, Shevchenko Blvd., Kyiv, Ukraine, 01601 \\ konsnizher@gmail.com
}

\begin{abstract}
Aim. Periodically emitted spiral waves of cAMP determine the directed movement of individual amoebae of Dictyostelium discoideum towards the aggregation centers, which are the sources of these waves. Overall behavior of cell population that includes at this stage the thousands of independent organisms, could be reproduced and visualized through 2D simulation modeling. Methods. Object-oriented Pharo programming language was applied to create the model. As the source of random numbers the explicit inversive congruential generator was used. The following processes were attributed to developing population of individual amoebae: appearance of randomly distributed initial cells/spores; the search of feeding substrate; mitosis; forming (depending on the local environment) of the active aggregation centers; periodical emittances of cAMP spiral waves from the aggregation centers; directed movement of the amoebae, which were captured by the cAMP wave, towards aggregation center. Results. In course of the simulation of the feeding and subsequent mitosis, small initial population of amoebae was multiplied and distributed in the borders of specified area. When reaching a finite population density, the appearance of few active aggregation centers took place. Spiral cAMP waves periodically propagated from these centers in $2 \mathrm{D}$ area of the model. The cells, which were "covered" by the wave, begun their movement to the corresponding aggregation center, intermitted with the periods of the rest. During migration the cells formed the characteristic "streams". Conclusion. This model could provide additional important information in the study of the phases and underlying mechanisms of self-organizing cell populations.
\end{abstract}

Keyw or d s: cAMP waves, cell aggregation, object-oriented programming language.

\section{Introduction}

Aggregation of the individual amoebae of Dictyostelium discoideum (Dictyos) into multicellular slugs (pseudoplasmodia) remains one of the most interesting and extensively used models of the cell population self-organization [1]. In fact, some basic questions of modern

(C) 2020 K. A. Nizheradze; Published by the Institute of Molecular Biology and Genetics, NAS of Ukraine on behalf of Biopolymers and Cell. This is an Open Access article distributed under the terms of the Creative Commons Attribution License (http://creativecommons.org/licenses/by/4.0/), which permits unrestricted reuse, distribution, and reproduction in any medium, provided the original work is properly cited 
biology and medicine (such as gene activation, receptor-signal transduction, cell-cell and cellmatrix interactions, cell migration) are still investigated with applying this enigmatic organism. If formulate the most important issues under study concerning this stage of Dictyos living cycle, they could be listed as follows:

a) spontaneous appearance of the active centers of aggregation after the period of starvation;

b) periodical emittance and propagation of the spiral waves of 3'-5'- cyclic adenosine monophosphate (cAMP) from these centers through the population of individual amoebae;

c) reaction and coordinated directed movement of the thousands of amoebae, which are "captured" by cAMP waves, to corresponding aggregation centers.

To investigate these processes, different laboratory technique, as well as the methods of mathematical modeling are used. As a result, a huge bulk of information on this phenomenon was obtained during past decades [2]. Special attention is paid to one of the central points of self-organization: emergence of the active centers of aggregation and cell inhomogeneity [3].

Nevertheless, the global behaviour of the whole cell population, comprising the hundreds of thousands of individual amoebae, needs to be modeled using appropriate and (preferably) not excessively complex tools [4]. In this regard, the biologically oriented paradigm of agent-based models seems to be very attractive and powerful computer-aided approach to resolve this problem [5]. According to the principle of agent-based modeling, the behaviour of every amoeba is governed by the set of simple rules, which determines the reaction of the object to external stimuli. For this work we used pure object-oriented Pharo programming language to create simulation model of cAMP wave-induced aggregation of Dictyos amoebae. This programming environment (as well as the corresponding tutorials) could be downloaded and installed from the site of developers (pharo.org) [6].

\section{Methods}

The latest stable 8.0 version of Pharo programming language (64-bit) was used to create the simulation model. To produce pseudorandom numbers, the explicit inversive congruential generator [7] was realized in Pharo and introduced into the model as a separate class. This generator was applied for random initial distribution of spores and undirected foraging movement (with random rotation angle) of individual amoebae during the growth phase of Dictyos. At each time-step the changed position of each moving amoeba was determined by using the direction cosine for the calculation of vector coordinates.

To provide visualization of the process under study, the main objects of the model (individual amoebae, wasted areas of substrate, active centers of aggregation, and the spiral waves of cAMP) were represented by Morphs, which are special visual objects. To differentiate the amoebae (moving, mitotic, aggregating and resting ones) they were attributed with different colours. In order to reduce the computational load, the number of these objects was limited to a few hundreds.

The aggregation centers appeared as a result of the fulfillment of two conditions:

a) increasing of the total number of amoebae, and

b) formation of small cell clusters. 
To reveal the cell cluster formation at this pre-aggregation stage, the distances (in pixels) between all the amoebae were analyzed.

Spiral wave propagation from the aggregation center (during the phase of aggregation) was based on polar equation of logarithmic spiral

$$
r=a e^{b \theta}
$$

where $\mathbf{r}$ - radius vector, $\mathbf{a}$ and $\mathbf{b}$ - parameters of spiral, and $\mathbf{e}-$ Euler's number.

At each step, the next vertex was added to developing spiral. To determine if the amoeba is already inside this wave, the radius vector of the wave was compared with the length of the vector between the amoeba and the corresponding aggregation center, and the angle between these two vectors was calculated. When the amoeba was "captured" by the wave, it began to move towards the corresponding aggregation center.

The initial source code of this simulation model (with additional commentaries) was hosted on SmalltalkHub repository.

\section{Results and Discussion}

The main three phases of the unfolding simulation model are presented in Fig. 1.

Initialization and growth phase. As the general frame for the simulation, there was the class DictyosteliumSimulation. When the instance of this class was created, it invoked and sequentially started (during the time-steps) all necessary objects, including the random number generator, collections, counters, virtual amoebae, and so on. This governing object determined the beginning and the end of the simulation process.

A small initial number (about 15) of individual amoebae was placed in the central part of designated area of the plane. Thereafter they started the foraging movements (16 pixels per step). If the amoeba took its position in a new "clean" place, this small region of food substrate was marked (and coloured) as "waste", so feeding is no longer possible here for the next amoeba, randomly attending this place. In the case if the amoeba reached the outer boundary, it returned to simulation area. After few successful foraging steps (usually 3 ) the cell entered the process of mitosis, and two new amoebae appeared instead of parent one (Fig. 2A).

Pre-aggregation phase. When the number of moving amoebae exceeded some threshold (we used the number of 300 amoebae to reach the necessary population density), the main part of the growth substrate was already converted into "waste land" (simulation of starvation), and the intensity of mitosis in the population essentially decreased. Then the active centers of aggregation appeared. Till now, this phenomenon is enigmatic, but probably, as it was mentioned above, is related to the cell inhomogeneity [3]. For modeling this process we used the finding of lattice "gems", described earlier for cultured human fibroblasts in the real (nonvirtual) experiment [8]. So, the second condition (besides abovementioned starvation) of emerged active centers was the formation of the compact cell clusters (containing 4 amoebae) located in close proximity (less than 16 pixels) to each other (Fig. 2B). The quantity of active centers was limited to 3 , and the distance between them was at least 200 pixels.

Aggregation phase. The propagation of cAMP spiral wave during Dictyos aggregation was studied and modeled extensively $[9,10]$. Consistently applying the paradigm of object- 


\section{Initialization and Growth phase}

- Model frame creation and distribution of the initial set of spores

- Undirected foraging movements of the amoebae

- Appearance of the waste areas, which will be not applicable for foraging

- Mitotic divisions and corresponding increase of the total amount of the amoebae

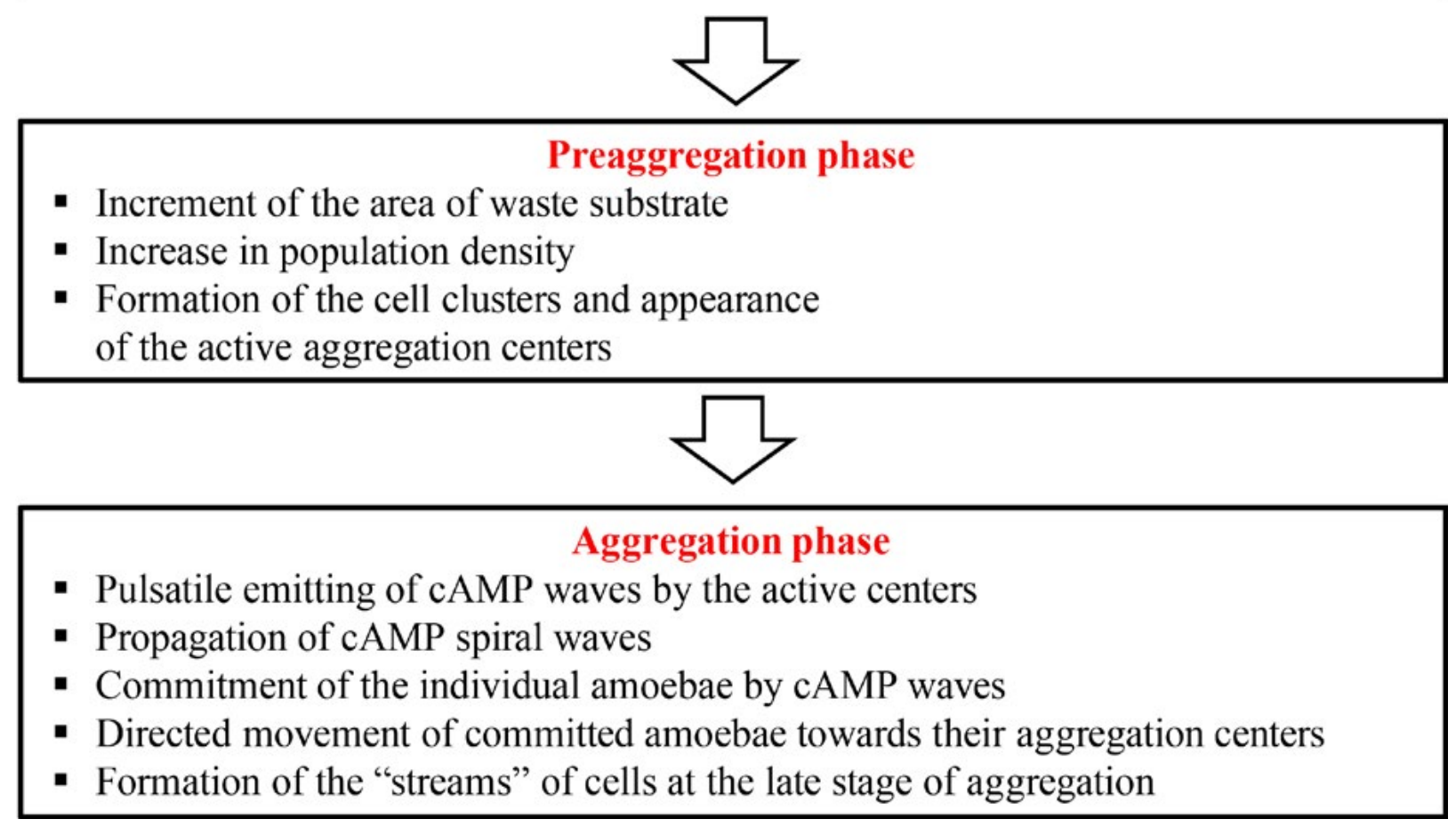

Fig. 1. The main processes inside the simulation model of Dictyos aggregation.

oriented modeling, we created the cAMP spiral waves as separate developing objects, periodically emitted from the aggregation centers. If the amoeba was "captured" by the wave, this cell became committed to corresponding aggregation center that is the source of this wave. This cell commitment to its "own" center was preserved for the next waves. A committed amoeba turned around and started its movement towards the centers, but after few steps (4 steps) the period of rest took place - until the next wave initiated the motion (Fig. 2C). The char- acteristic feature of the aggregation was the formation of cell "streams", that reproduced the picture of Dictyos aggregation in reality (Fig. 2D). The process stopped when the vast majority of individual amoebae transited to their places of gathering.

\section{Conclusion}

This computer model is a comprehensive simplification of real Dictyos aggregation. We have not input the available data concerning the chemical messengers, produced by the 

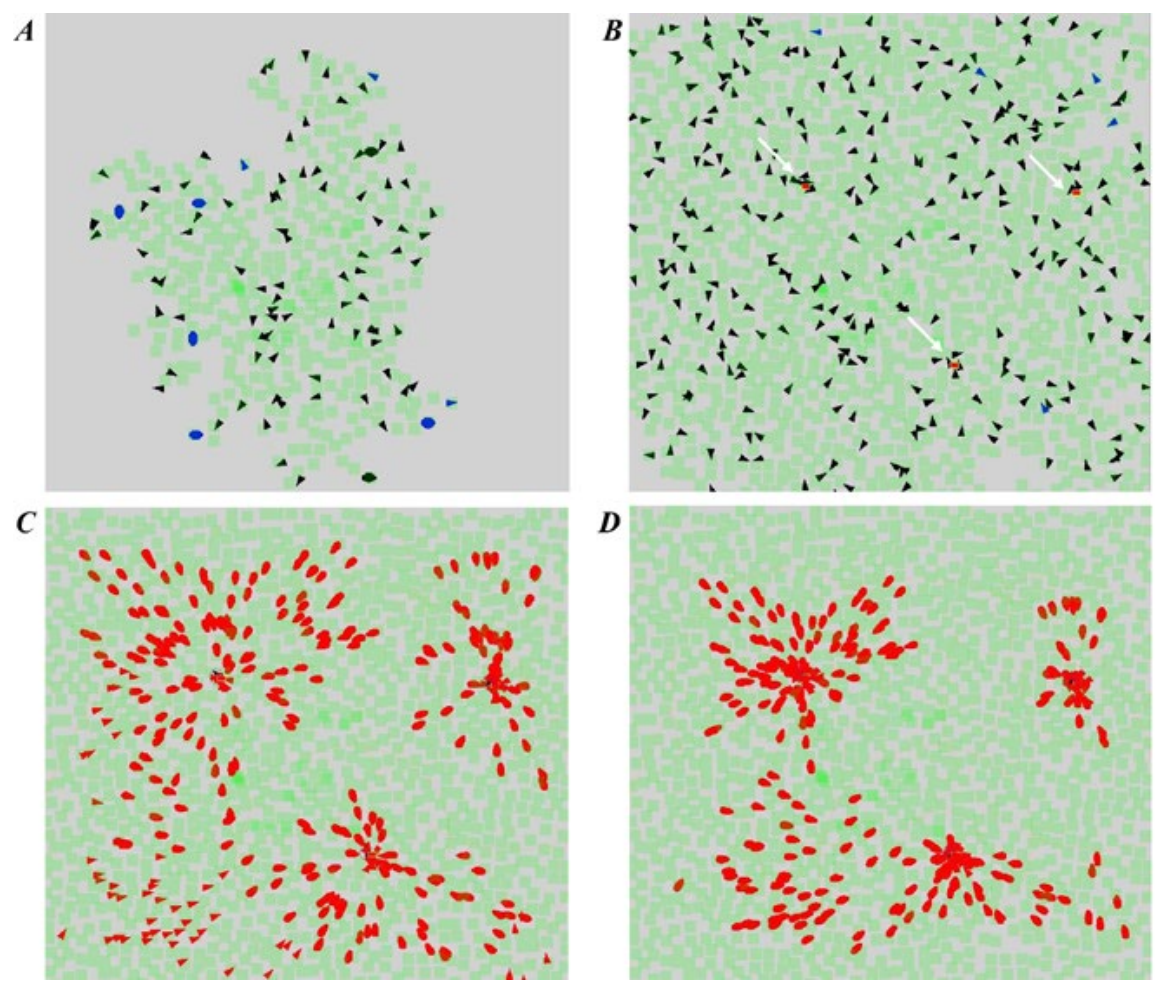
$\boldsymbol{\Lambda}$ - moving amoeba
$\boldsymbol{\Lambda}$ - feeding amoeba
$\Delta$ - committed amoeba
— waste substrate
— beginning of mitosis
— end of mitosis
I - active center of aggregation
— resting committed amoeba

Fig. 2. Sequential phases of the simulation of Dictyos population growth and aggregation (typical realization of the model). $A$ - foraging movements and growth, 70 time-steps. $B$ - starvation and active centers appearance; white arrows point to the active centers of aggregation, 173 time-steps. $C$ - initial stage of aggregation, 255 time-steps. $D-$ formation of cell "streams", 305 time-steps.

amoebae, such as the prestarvation factor (PSF) or the counting factor (CF). The processes of cAMP spiral wave propagation and reaction of individual cells to this attractant were presented at the macro-level and did not engage underlying molecular mechanisms [11]. But even in such a simplified form, this model makes it possible to reproduce the main stages of this process. The use of object-oriented programming allows us to set a number of explainable rules for each cell and evaluate the behavior of the entire population. For future application, this model can be constantly updated and supplemented with new data on the mechanisms of intracellular signaling and intercellular interactions. Such an application is especially interesting and useful in the context of investigating 3D-2D transition of cultured mammalian cells [12], and the role of cellular rhythms $[13,14]$ in self-organization of homo-and heterotypic cell populations.

\section{Acknowledgments}

The author wishes to thank Dr. S. Ducasse for the valuable advice on the source code of the model. 


\section{REFERENCES}

1. Bonner JT. Evolution of development in the cellular slime molds. Evol Dev. 2003;5(3):305-13.

2. Kessin RH. Dictyostelium: evolution, cell biology, and the development of multicellularity. Cambridge: “Cambridge University Press", 2001; 294 p.

3. Vidal-Henriquez E, Gholami A. Spontaneous center formation in Dictyostelium discoideum. Sci Rep. 2019;9(1):3935.

4. MacKay $S A$. Computer simulation of aggregation in Dictyostelium discoideum. J Cell Sci. 1978;33:1-16.

5. Parhizkar M, Di Marzo Serugendo G. Agent-based models for first- and second-order emergent collective behaviours of social amoeba Dictyostelium discoideum aggregation and migration phases. Artif Life Robotics. 2018;23: 498-507.

6. Ducasse S, Chloupis D, Hess N, Zagidulin D. Pharo by Example 5. "Lulu.com \& Square Bracket Associates", 2017; 352 p.

7. Hellekalek $P$. Good random number generators are (not so) easy to find. Math Comput Simulat. 1998;46(5-6):485-505.

8. Nizheradze $K A$. Binding of wheat germ agglutinin to extracellular network produced by cultured human fibroblasts. Folia Histochem Cytobiol. 2000;38(4):167-73.

9. Martiel JL, Goldbeter A. A Model Based on Receptor Desensitization for Cyclic AMP Signaling in Dictyostelium Cells. Biophys J. 1987;52(5):807-28.

10. Bhowmik A, Rappel WJ, Levine H. Excitable waves and direction-sensing in Dictyostelium discoideum: steps towards a chemotaxis model. Phys Biol. 2016;13(1):016002.

11. Goldbeter A. Oscillations and waves of cyclic AMP in Dictyostelium: a prototype for spatio-temporal organization and pulsatile intercellular communication. Bull Math Biol. 2006;68(5):1095-109.

12. Kravchenko AO, Kosach VR, Shkarina KA, Zaiets $I V$, Tykhonkova IO, Khoruzhenko AI. Optimization of in vitro model for analysis of tumor cell migration dynamics. Biopolym Cell. 2018; 34(6):477-86.

13. Nizheradze KA, Efimov AS. Study of the dynamics of epithelioid outgrowth of skin explants of healthy people and the patients with insulin-dependent dia- betes mellitus. Dopov Nac Akad Nauk Ukr. 1993;(9):165-71.

14. Goldbeter A, Gérard C, Gonze D, Leloup JC, Dupont $G$. Systems biology of cellular rhythms. FEBS Lett. 2012;586(18):2955-65.

\section{Імітаційне моделювання цАМФ індукованої агрегації Dictyostelium за допомогою об'єктно- оріснтованої мови програмування Pharo}

К. О. Ніжерадзе

Передумови. Періодично випромінювані спіральні хвилі цАМФ визначають спрямований рух окремих амеб Dictyostelium discoideum до центрів агрегації, які $\epsilon$ джерелом цих хвиль. Загальна поведінка клітинної популяції, яка включає на цьому етапі тисячі незалежних організмів, може бути відтворена та візуалізована за допомогою двовимірного імітаційного моделювання. Методи. Для створення моделі було застосовано об'єктно-орієнтовану мову програмування Pharo. В якості джерела випадкових чисел використовувався інверсний конгруентний генератор. 3 розвитком популяції окремих амеб були пов'язані такі процеси: поява випадково розподілених початкових клітин/спор; пошук поживного субстрату; мітоз; формування (залежно від локального середовища) активних центрів агрегації; періодичні випромінювання центрами агрегації спіральних хвиль цАМФ; спрямований рух амеб, захоплених хвилею цАМФ, до центру агрегації. Результати. В ході симуляції пошуку їжі та подальших мітозів невелика початкова популяція амеб кількісно зростала та розподілялась у визначених межах. При досягненні кінцевої щільності популяції відбувалося утворення кількох активних центрів агрегації. Спіральні хвилі цАМФ періодично поширювались 3 цих центрів у 2D області моделі. Клітини, «захоплені» хвилею, розпочинали рух до відповідного центру агрегації, цей рух чергувався із періодами спокою. У ході міграції амеби утворювали характерні «потоки» клітин. Висновок. Створена модель може надати додаткову важливу інформацію при вивченні фаз та основних механізмів процесу самоорганізації клітинних популяцій.

Кл юч о в і с л о в а: Хвилі цАМФ, агрегація клітин, об'єктно-орієнтована мова програмування. 


\section{Имитационное моделирование цАМФ индуцированной агрегации Dictyostelium при помощи объектно-ориентированного языка программирования Pharo}

\section{К. А. Нижерадзе}

Предпосылки. Периодически испускаемые спиральные волны цАМФ определяют направленное движение отдельных амеб Dictyostelium discoideum к центрам агрегации, которые являются источниками этих волн. Общее поведение популяции клеток, которая включает на данном этапе тысячи независимых организмов, можно воспроизвести и визуализировать с помощью имитационного 2D-моделирования. Методы. Для создания модели был применен объектно-ориентированный язык программирования Pharo. В качестве источника случайных чисел использовался инверсный конгруэнтный генератор. С развитием популяции отдельных амеб были связаны следующие процессы: появление случайно распределенных исходных клеток/спор; поиск питательного субстрата; митоз; формирование (в зависимости от локального окружения) активных центров агрегации; периодическая генерация спиральных волн цАМФ из центров агрегации; направленное движение амеб, которые были захвачены волной цАМФ, к центру агрегации. Результаты. В ходе симуляции поиска пищевого субстрата и последующих митозов небольшая начальная популяция увеличивалась количественно и распределялась в границах указанной области. При достижении конечной плотности популяции амеб имело место появление нескольких активных центров агрегации. Спиральные волны цАМФ периодически распространялись от этих центров в 2D области модели. Клетки, «захваченные» волной, начинали движение к соответствующему центру агрегации, это движение чередовалось с периодами покоя. В ходе миграции амебы образовывали характерные «потоки» клеток. Вывод. Данная модель может предоставить дополнительную важную информацию при изучении фаз и основных механизмов процесса самоорганизации клеточных популяций.

Кл юч е в ы е с л о в а: Волны цАМФ, агрегация клеток, объектно-ориентированный язык программирования.

Received 03.07.2020 